\title{
Lise Öğrencileri İçin Analitik Düşünme Ölçeği Geliştirme Çalışması
}

\section{Developing Analytical Thinking Scale for High School Students}

\author{
Prof. Dr. Gürbüz OCAK ${ }^{(D)}$, Ferat PARK (iD)2
}

$\ddot{\mathbf{O z}}$

Bu çalışmada lise öğrencilerinin analitik düşünme düzeyleri belirlenmeye çalışılııştır. Araştırmanın örneklemini, 2017-2018 eğitim-öğretim yılında, Afyonkarahisar ilinde öğrenim gören 297 lise öğrencisinden oluşmaktadır. Araştırmada karma yöntemlerden olan keşfedici ardışık desen kullanılmıștır. $\mathrm{Bu}$ araştırmada 24 maddelik beşli likert tipinde lise öğrencileri için analitik düşünme ölçeği geliştirilmiştir. Ölçek 1. faktörde (bilgiyi özümseme) 0.449 - 0.734 arasında faktör yükleri olan 10 madde, 2. faktörde (ayrıntılara dikkat etme) $0.590-0.772$ arasında faktör yükleri olan 6 madde, 3. faktörde (çözümleme) 0.617 - 0.769 arasında faktör yükleri olan 4 madde ve 4. faktörde (çalışma stratejisi) 0.646 0.758 arasında faktör yükleri olan dört alt faktörden oluşturulmuştur. Geliştirilen ölçeğin alt boyutlarının cronbach alfa katsayıları $0.867,0.840,0.774$ ve 0.741 ve ölçeğin tüm güvenirlik katsayısı 0.908 olarak hesaplanarak güvenilir olduğu sonucuna varılmıștır. Araştırma sonucunda 24 maddelik, 4 alt boyuta sahip, 5'li likert tipinde ve güvenilir bir ölçek elde edildiği söylenebilir. Araştırmanın son bölümünde doğrulayıcı faktör analizi çalışmaları gerçekleştirmiş ve uyum iyiliği indekslerinin mükemmel ve kabul edilebilir düzeyde olduğu belirlenmiştir.

Anahtar Kelimeler: Analitik düşünme, lise öğrencileri

Makale Türü: Araştırma

\begin{abstract}
In this study, analytical thinking levels of high school students is tried to be determined. The sample of the research is 297 high school students in Afyonkarahisar city center in 2017-2018 academic year. The exploratory sequential pattern, which is a mixed method in research. It creates a 5-point Likert-type scale consisting of 24 items to obtain the data. The scale has four factors, 10 items with factor loads between 0.449 and 0.734 in factor 1 (factor assimilation), 6 items with factor loads between 0.590 and 0.772 in factor 2 (attention to detail), $0.617-0.769$ in factor 3 (analysis) It is composed of 4 factors with factor loads and four sub-factors with factor loads between 4 and 4 factors (working strategy) between 0.646 and 0.758 . The cronbach alpha coefficients $0.867,0.840,0.774$ and 0.741 indicate that it is reliable to calculate the cronbach alpha coefficient 0.908 for the overall reliability of the scale. In the research, a reliable scale with 24 items, 4 sub-dimensions, 5-point likert type can be obtained. It is in excellent and acceptable condition.
\end{abstract}

Keywords: Analytical thinking, high school students

Paper Type: Research

\footnotetext{
${ }^{1}$ Afyon Kocatepe Üniversitesi, Eğitim Fakültesi, gocak@gmail.com.

${ }^{2}$ Afyon Kocatepe Üniversitesi, Sosyal Bilimler Enstitüsü, feratpark@gmail.com.
}

Atıf için (to cite):Ocak, G. ve Park, F (2019). Lise öğrencileri için analitik düşünme ölçeği geliştirme çalışması. Afyon Kocatepe Üniversitesi Sosyal Bilimler Dergisi, 22(1), 49-68. 


\section{Giriş}

İnsanoğlunun dünyaya geldiği günden itibaren düşünmeye olan ihtiyacı artmaktadır. Her bir düşünme yeni bir düşünme biçimine olan ihtiyacı arttırmaktadır. Öyle ki gerek yaşamı süresince karşılaş̧ı̆̆1 problemlerin çözümünde zihinsel bir süreç olan düşünme faaliyetini gerçekleştirmek zorundadır. Problemlerin çeşitliği arttıkça düşünme biçimleri de değişmektedir. Eleştirel düşünme, yansitıcı düşünme, analitik düşünme vb. her biri yeni bir problemin çözümünde etkili olan düşünme biçimleridir. Problemlere göre şekillenen düşünme biçimleri zihinsel faaliyetlerin çeşitlenmesine ve bunun da bir eğitim ihtiyacı olarak gündeme gelmesine neden olmuştur. $\mathrm{Bu}$ durum eğitim alanında zihinsel becerilere odaklı eğitimi gündeme getirmiştir. Günümüzde öğrenciler bir bütün olarak ele alınmakta ve yapılan eğitim etkinlikleri öğrencilerin başta zihinsel olmak üzere tüm beceri alanlarını üst düzeyde geliştirmeye odaklanmaktadır. Zihinsel becerilerin kalbinin düşünme ve sorgulama olduğu, düşünme ve sorgulamanın, bireyin zihinsel işlem ve süreçlerini harekete geçirdiği, problem çözme, karar verme ve kavramlaştırma becerilerini geliştirdiği belirtilmektedir (Güneş, 2012). Düşünme sorgulamayı gerektirir, sorgulama araştırma ve yaratıcılığı geliştirir. Düşünmenin olduğu yerde saplantılar olmaz, ancak yorgunluk olur, yenilik olur.

Düşünme: "İçinde bulunulan durumu anlayabilmek amacıyla yapılan aktif, amaca yönelik zihinsel bir süreçtir" (Cüceloğlu, 1999). Analitik düşünme ise, "Bütünün parçalarına ayrılması, onların yeniden tanımlanması ve sınıflandırılmasına yönelik işlemleri kapsamaktadır. Çözümlemeye dayalı bir düşünme biçimidir." (Güneş, 2012). Analitik düşünme becerisine sahip olan bireyler, bir problemin çözümüne ulaşmayı hedefledikleri zaman problemin belirgin parçalarını ve özelliklerini düşünebilmektedir (Malloy ve Jones, 1998). Detaylara odaklanan analitik bireyler ardışık ve sıralı olarak problemleri çözüme kavuşturmaktadırlar. Analitik düşünebilen öğrenciler problemleri alt problemlere ayırabilmekte, süreç içindeki adımları tanımlayabilmekte ve yapmayı varsaydıkları her adımı anlatabilmektedirler (Dewey, 2007). Sternberg (2006) analitik düşünmeyi dört basamaklı olarak ele almaktadır. 1) Bir problemi önce parçalara ayırmak ve ayrılan parçaları anlamlandırmak, 2) Problemin oluşma nedenlerini ve çözüm basamaklarını açıklamak, 3) Toplanan bilgi ve olaylar arasında karşılaştırma yapmak, 4) Ortaya çıkan verileri değerlendirmek ve eleştirerek sonuca ulaşmak.

Özetle, analitik düşünebilen bireyler, bir durum ya da bilginin neyi ne biçimde etkileyebileceğini veya ne gibi sonuçlar ortaya koyabileceğini görebilmektedirler. Analitik düşünme becerisine sahip olan bireyler firsatları görebilmekte, krizleri önleyebilmekte veya kriz ortamında hızlı ve doğru bir şekilde çözebilmektedirler (Parlar, 2016). Bundan dolayı da bireylerin analitik düşünce becerilerinin geliştirilmesi önem arz etmektedir.

Analitik düşünce becerilerine yönelik yurtiçinde yapılan çalışmalar bulunmaktadır. Bu çalışmaların bazılarından aşağıda bahsedilmektedir.

Umay ve Arıl (2011) öğretmen adayları üzerinde gerçekleştirdikleri araştırmalarında, bütüncül ve analitik düşünme stillerinin matematik problemlerini çözme performansları ve seçilen çözüm yolları üzerinde nasıl bir etkisi olduğunu incelemeyi amaçlamışlardır. Araştırma sonucunda bütüncül ve analitik düşünme stiline sahip öğretmen adaylarının problem çözme performanslarının istatistiksel olarak farklılık göstermediğini saptamışlardır.

Sebetçi ve Aksu (2014) bilgisayar programcılı̆̆ı eğitimi alan öğrencilerin mantıksal ve analitik düşünme becerilerinin programlama dilleri başarısı üzerindeki etkisinin belirlenmesi amacıyla gerçekleştirdikleri çalışmalarında, öğrencilerin analitik ve mantıksal düşünme becerilerinin programlama başarılarını artırdığını belirlemiş̧lerdir.

Akkuş-Çakır ve Senemoğlu (2016) üniversite öğrencilerinin analitik düşünme beceri düzeylerini incelemek ve bu becerilerin gelişimini etkileyen etmenleri belirlemek amaciyla gerçekleştirdikleri çalışmalarında, üniversite öğrencilerinin analitik düşünme becerilerini düşük 
seviyede olduğunu tespit etmişler ve üniversitede alınan eğitimle analitik düşünme becerilerinin geliştiğini, ancak istenilen düzeye erişilemediği sonucuna varmışlardır.

İncelenen araştırmalarda, analitik düşünme becerisi alanlara göre farklı sonuçlar göstermektedir. $\mathrm{Bu}$ nedenle güvenilir sonuçlara ulaşabilmek için analitik düşünme becerisine yönelik daha fazla araştırmaya ihtiyaç duyulmaktadır. Bu araştırmalarda da öncelikle bireylerin analitik düşünme becerilerinin doğru biçimde ölçülmesi, ardından diğer değişkenlerle ilişkilerine bakılması gerekmektedir. Lakin yapılan araştırmaların genellikle durum saptamaya yönelik olduğu, ölçek olarak yabancı kökenli ölçeklerin tercih edildiği görülmektedir. Ülkemiz alanyazınında ise ölçek olarak Umay ve Arıol(2011)'un çalışmalarında kullandıkları "Problem Çözerken Bütüncül ve Analitik Düşünme Ölçeği” dikkat çekicidir. Bunun dişında ölçek geliştirme açısından analitik düşünme becerilerine yönelik bir çalışmaya rastlanılmamıştır. Bu çalışmanın analitik düşünme becerilerini saptamaya yönelik alanyazındaki bu boşluğu dolduracağg düşünülmektedir.

\section{Yöntem}

$\mathrm{Bu}$ çalışma kapsamında, lise öğrencilerinin analitik düşünme düzeylerini belirlemeye yönelik bir ölçeğin geliştirilmesi amaçlanmıştır. Bu araştırmanın yöntemi, nitel ve nicel veri toplama tekniklerinin beraber kullanıldığı karma yöntemdir. Karma yöntem kapsamında ilk olarak nitel veriler toplanarak nicel verilerin desteklendiği keşfedici ardışı desen olarak tasarlanmıştır (Creswell ve Plano Clark, 2011). Araştırma süreci, ölçek geliştirme hazırlanan görüşme sorularıyla toplanan nitel veriler; toplanan verilerin analizine ve alanyazına uygun olarak maddelerin yazılması ve uygulanarak elde edilen verilerin analizi ve yorumlanması devam edecektir. Bu araştırmanın nitel basamağı tekli durum çalışması (Creswell, 2013), nicel basamağını ise tarama çalışması (Fraenkel, Wallen, ve Hyun, 2011) olarak desenlenmiştir. Bu çalışmadaki durum, lise öğrencilerinin analitik düşünme düzeyleridir.

Çalışmanın katılımcıları, toplanacak verilerin özelliğine ve toplanma şekline göre farklı örnekleme yöntemleri ile belirlenmiştir. Çalışmada yararlanılan örnekleme yöntemi ve örneklemi Tablo 1'de verilmiştir.

Tablo 1. Lise öğrencileri için analitik düşünme ölçeğini geliştirmek amaciyla belirlenen örneklemler

\begin{tabular}{ccc}
\hline Veri toplama aracı & Örnekleme Yöntemi & Örneklem \\
\hline Yazılı görüş formu & Kolay ulaşılabilir örnekleme & 12 \\
\hline $\begin{array}{c}\text { Ön uygulama } \\
\text { (maddelerin anlaş1lırlığı) }\end{array}$ & Kolay ulaşılabilir örnekleme & 20 lise öğrencisi \\
Pilot uygulama & Kolay ulaşılabilir örnekleme & 31. Ve 12. Sinıf) \\
\hline (madde analizleri) & & $(9 .$, 10., 11. Ve 12. Sinıf) \\
\hline
\end{tabular}

Tablo 1'e göre, analitik düşünme ile ilgili kategorilerin belirlenmesi için Afyonkarahisar il merkezinde lise düzeyinin çeşitli seviyelerinde 2017-2018 eğitim öğretim yılında öğrenim görmekte olan 12 lise öğrencisine "Analitik Düşünme Görüş Formu" uygulanmıştır. Analitik Düşünme Görüş Formu aracılığıyla toplanan verilerin analizi neticesinde çeşitli kategoriler elde edilmiştir. Kategoriler doğrultusunda madde havuzu oluşturularak uzman görüşüne başvurulmuş ve ölçeğe son hali verilmiştir. Bu maddelerin anlaşılırlığının kontrolü için Afyonkarahisar il merkezinde lise düzeyinin çeşitli seviyelerinde 2017-2018 eğitim öğretim y1lında öğrenim görmekte olan 20 öğrenciye okutturulmuştur. Gelen dönütler dikkate alınarak pilot uygulama Afyonkarahisar ilinin çeşitli semtlerinde kolay ulaşılabilir örnekleme yöntemiyle belirlenen 2017-2018 öğretim yılında çeşitli devlet okullarının farklı lise seviyelerinde öğrenim gören 324 öğrenciye uygulanmıştır. Ancak ölçeği yönergeye uygun ve samimi bir şekilde doldurmayan 27 lise öğrencisinin verileri değerlendirme dış1 bırakılmıştır. Öğrenciler için Ö1, Ö2, Ö3... şeklinde devam eden kodlar kullanılarak 297 öğrenciden elde edilen veriler analiz edilmiştir. 
$\mathrm{Bu}$ bilgilerin 1şığında, araştırmaya katılan lise öğrencilerinin, analitik düşünme düzeylerine ilişkin yeterli seviyede bilgi ve görüş aktarabilecek düzeyde oldukları düşünülmektedir.

\subsection{Katılımcılar}

Genel bir kural olan, değişken sayısının beş katı olması gereken örneklem sayısı için, özellikle faktörler güçlü ve belirgin olduğu durumlarda, 100 ile 200 arasındaki örneklem büyüklüğü yeterli görülmektedir (Büyüköztürk, 2002). Araştırmada veriler, 2017-2018 eğitim öğretim y1lında Afyonkarahisar merkeze bağlı liselerde öğrenim görmekte olan 324 lise öğrencisinden toplanmıştır. Yönergeye uygun ve samimi şekilde doldurulmadığı düşünülen 27 lise öğrencisinin ölçeği değerlendirme dışında tutulmuştur. Araştırmaya katılmayan ölçekler çıkarıldığında, 297 adet lise öğrencisinden elde edilen veriler üzerinden çalışma yürütülmüştür. Seçkisiz olmayan örnekleme yöntemlerinden, uygun örnekleme yöntemi ile seçilen 73 kişi 9. sınıf, 138 kişi 10. sınıf ve 86 kişi 11. sınıf olmak üzere 169 kadın ve 128 erkek öğrenci katılmıştır.

Tablo 2. Öğrencilerin demografik bilgilerinin dağılımı

\begin{tabular}{lll}
\hline Demografik Özellikler & & $\mathrm{N}$ \\
\hline & 9. Sinıf & 73 \\
Sinıf Düzeyi & 10. Sinıf & 138 \\
& 11. Snnff & 86 \\
Toplam & & 297 \\
\hline
\end{tabular}

\section{2. Ölçme Aracının Geliştirilmesi}

Lise öğrencilerinin analitik düşünme düzeyini ölçmek amaciyla geliştirilen bu ölçek, 5'li likert tipindedir. Ölçeğin maddelerine verilen tepkiler uygun değil seçeneğinden tamamen uygun seçeneğine doğru beş dereceden oluşmaktadır. Ölçekten alınan puan yükseldikçe analitik düşünme artışı gözlemlenmektedir. Ölçeğin geliştirilmesi için yapılanlar aşamalı olarak aşağıda başlıklar olarak belirtilmiş ve aşamaları şekil 1'de gösterilmiştir.

Şekil 1. Ölçme aracının geliştirilme aşamaları

\begin{tabular}{l}
\hline Literatür taraması ve görüşme sorularının oluşturulması \\
\hline Görüşme yapılması ve anahtar kavramların belirlenmesi \\
\hline Madde havuzu hazırlanması ve uzman görüşünün alınması \\
\hline Ön uygulama ve düzeltmelerin yapılması \\
\hline Lise öğrencilerine Pilot uygulama \\
\hline Açımlayıcı faktör analizi \\
\hline Cronbach-alfa güvenirlik hesab1 \\
\hline Üst gurp-Alt grup güvenirlik analizi \\
\hline Ölçek maddelerinin kesinleştirilmesi \\
\hline Doğrulayıcı faktör analizi
\end{tabular}




\subsubsection{Nitel Veriler}

Tablo 3. Lise öğrencileri için analitik düşünme ölçeğinin geliştirilmesinde kullanılan nitel süreç ve ürünler

\begin{tabular}{|c|c|c|c|}
\hline & Nitel Veri Toplama & Nitel Veri Analizi & Ölçme Aracını Geliştirme \\
\hline \multirow{3}{*}{ 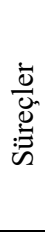 } & Kolay ulaş1labilir örnekleme & Açık Kodlama & $\begin{array}{c}4 \text { kategoriyi ölçeğin alt } \\
\text { faktörleri olarak ele alma }\end{array}$ \\
\hline & $\begin{array}{c}\text { Analitik düşünmeye yönelik } \\
\text { görüşme formu }\end{array}$ & Kategori Oluşturma & $\begin{array}{c}\text { Madde havuzu } \\
\text { oluşturulması }\end{array}$ \\
\hline & & & $\begin{array}{c}\text { Maddelerin anlaş1lırlık } \\
\text { kontrolü }\end{array}$ \\
\hline \multirow{2}{*}{ 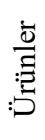 } & $\begin{array}{l}\text { Görüşme formu } \\
\text { dokümanları }\end{array}$ & & $\begin{array}{l}39 \text { maddelik pilot uygulama } \\
\text { formu }\end{array}$ \\
\hline & & $\begin{array}{l}\text { Analitik Düşünmeye } \\
\text { İlișkin } 4 \text { Altboyut }\end{array}$ & \\
\hline
\end{tabular}

Çalışmanın ilk kısmında lise öğrencilerinin analitik düşünme düzeylerini betimlemek amacıyla Analitik Düşünme Görüş Formu hazırlanmıştır. Formun geliştirilmesinde, 3 uzmanın görüşlerine başvurularak Tablo 3'de yer verilen 5 açı uçlu soru 12 adaya ayrı ayrı sorulmuştur. Elde edilen veriler, 3 eğitim programları alanında uzman kişi ile içerik analizi yapılmıştır. İçerik analizi, analiz edilen verilerin kapsamındaki temel konuları ve temel konu alanlarına dahil olan özel alt konu alanları oluşturmak için yararlanılan kategorileştirme sistemidir (Tavşancıl ve Aslan, 2001).

Araştırmada nitel veriler, daha önce nitel veri incelemesi yapmış olan üç kişi tarafından birbirinde bağımsız olarak incelenerek kodlanmıştır. Her katılımcının cevapları üçer defa gözden geçirilerek uzmanların oluşturdukları kodlar bir araya getirilmiş ve karşılaştırma yapılmıştır. Kategori ve isim olarak uyumsuz olan kodlarda yeniden yapılan incelemeyle birliktelik sağlanmıştır. Bu süreç sonunda, uzmanlar arası uyum katsayısı, "Güvenirlik = Görüş birliği / (Görüş Birliği + Görüş Ayrılı̆̆ı) x 100” formülüyle \%85 olarak hesaplandığ görülmektedir. Güvenirlik katsayısı $\% 70$ in üzerinde olduğu için ölçeğin madde yazma kategorilerinin güvenilir şekilde oluşturulduğu söylenebilir (Miles ve Huberman, 1994; akt: Ocak, G, Ocak, İ. ve Saban, 2013).

\subsubsection{Nicel Veriler}

Tablo 4. Lise öğrencileri için analitik düşünme ölçeğinin geliştirilmesinde kullanılan nicel süreç ve ürünler

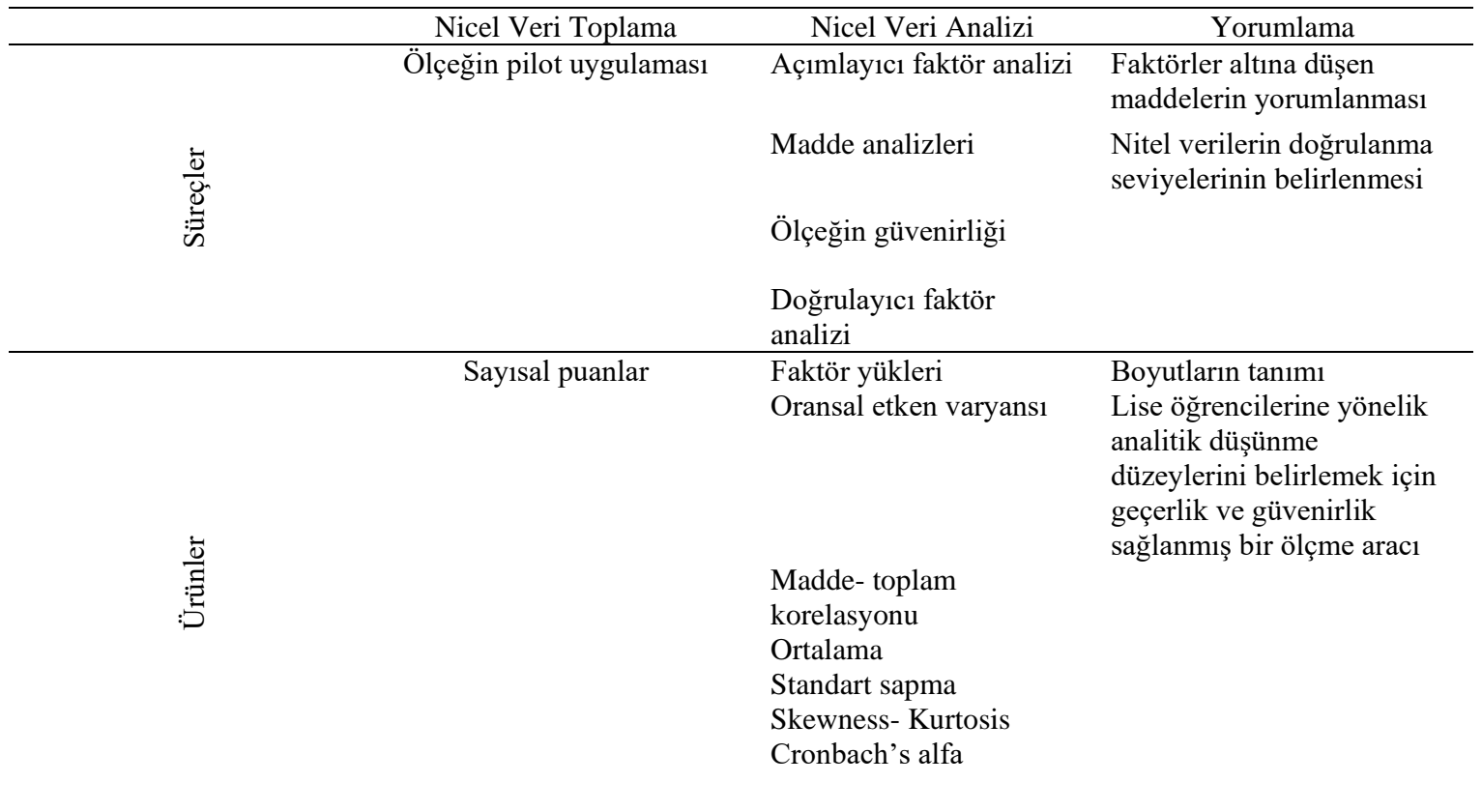


Öğrencilerin Analitik Düşünme Görüş Formuna verdikleri cevaplar doğrultusunda elde edilen dört kategoriye uyumlu bir biçimde uzman görüşleri dikkate alınarak ölçek maddeleri yazılmıştır. $\mathrm{Bu}$ kapsamda bir madde havuzu oluşturulmuştur. Ölçekteki maddelerin derecelendirilmesi için 5'li Likert tipinde bir derecelendirme kullanılmıştır. Buradaki yüksek puanlar, analitik düşünme düzeyinin yüksek olduğunu temsil etmektedir.

Maddeler anlaşılabilirliği ve amaca uygunluğu açısından daha önce ölçek geliştirme dersi almış ve çalışma yapmış olan uzmanların incelemesine sunulmuştur. Uzman dönütlerine göre, havuzdaki maddelerin bazıları çıkarılmış veya değiştirilerek pilot uygulamaya hazır 39 madde belirlenmiştir. Pilot uygulama için belirlenen 39 madde anlaş1labilirliğin sağlanabilmesi adına yeniden uzman görüşüne sunulmuştur. Gerekli düzeltmelerden sonra, ölçek maddelerinin anlaşılırlığını test etmek için 20 lise öğrencisine maddeler uygulanmıştır. Uygulama esnasında ögrenciler gözlenmiş ve verdikleri dönütlere göre düzenlenen tüm maddeler anlaşılır hale getirilmiştir.

Araştırma kapsamında geliştirilen ölçek, Afyonkarahisar il genelindeki devlet okullarının lise düzeyinin çeşitli sınıf seviyelerinde (9., 10., 11., 12. sınıf) öğrenim gören 324 öğrenciye uygulanmış ve daha önce bahsedilen sebeplerle 297 kişiden toplanan cevaplar analiz edilmiştir. Elde edilen verilere, açımlayıcı faktör analizi (AFA), madde analizleri ve doğrulayıcı faktör analizi (DFA) uygulanmıştır. İlk olarak ölçek maddelerinin açımlayıcı faktör analizine uygunluğunun tespit edilmesi için Kaiser-Mayer-Olkin (KMO) ve Bartlett's Test of Spherecity (BTS) testinden elde edilen bulgular incelenmiştir. Benzer şekilde ölçekteki maddelerin ayırt edicilik düzeylerinin belirlenmesi için \%27'lik alt-üst grup karşılaştırmaları yapılarak düzeltilmiş madde toplam korelasyonu hesaplanmıştır. Her altboyut için gruplar arasındaki farkların belirlenmesi amacıyla t-testi yapılmıştır. Ölçeğin güvenirliğinin tespiti Cronbach alfa katsayısıyla geçerliliğinin tespiti ise doğrulayıcı faktör analizi ile yapılmıştır.

\subsubsection{Madde Havuzunun Oluşturulması}

Öncelikle literatür taraması ile, analitik düşünme ile ilgili çalışmalar incelenmiştir (Çelik, Gürpınar, Başer ve Erdoğan, 2015; Umay ve Arıl, 2011; Akkuş-Çakır ve Senemoğlu, 2016; Haciömeroğlu, E. S., Haciömeroğlu, G., Güzel ve Kula, 2014; Fidan, 2018; Kavak, Kazancı Sunaoğlu ve Taner, 2017; Parlar, 2016).Yapılmış olan literatür taraması sonucu analitik düşünmenin, yeni fikir ve projeler üretme isteği, bir problem durumuna farklı çözüm yolları aramayı sevme, ayrıntılarla ilgilenme, yeni/özgün fikirler üretme, tablolarla çalışmaktan zevk alma kategorize etme, kanıtlamayı sevme, problemlerin farkına varma, neden- sonuç ilişkisi kurma, analiz etme isteği şeklinde anahtar kavramlar oluşturulmuştur. Bu aşamadan sonra lise öğrencileri ile benzer özellik taşıyan 12 öğrenciye anahtar kavramlar kapsamında, 5 açık uçlu soru sorulmuştur. Sorular tablo 5'te listelenmiştir.

Tablo 5. Literatür taraması sonucu belirlenen anahtar kavramlar kapsamında sorulan açık uçlu sorular

\begin{tabular}{ll}
\hline & SORULAR \\
\hline 1 & Sizce analitik düşünmek ne demektir? \\
2 & Analitik düşünmeyi etkileyen faktörler nelerdir? \\
3 & Analitik düşünmek günlük hayatımızda ne işimize yarar? \\
4 & Analitik düşünme becerimizi nasıl geliştirebiliriz? \\
5 & Analitik düşünen bireylerin özellikleri nelerdir? \\
\hline
\end{tabular}

Öğrencilere sorulan açık uçlu sorulara alınan cevaplara göre anahtar kavramlar oluşturulmuş ve anahtar kavramlar ile madde yazılmasına başlanmış ve soru havuzu oluşturulmuştur. Madde havuzunda 39 madde oluşturulmuştur.

Görüşme sorularından alınan cevaplar ve literatür taraması sonucu analitik düşünmeye yönelik; yeni fikir ve projeler üretme isteği, bir problem durumuna farklı çözüm yolları aramayı sevme, ayrıntılarla ilgilenme, yeni/özgün fikirler üretme, tablolarla çalışmaktan zevk alma 
kategorize etme, kanıtlamayı sevme, problemlerin farkına varma, neden- sonuç ilişkisi kurma, analiz etme isteği şeklinde anahtar kavramlar oluşturulmuştur.

Oluşturulan anahtar kavramlardan problem çözümüne yönelik irdeleme, sonuçların sağlamasını yapma, problem durumunu anlama, çözüm için gerekli bilgilere ulaşma, neden sonuç ilişkisi kurma, problemlerin farkına varma altında hazırlanan maddeler bilgiyi özümseme olarak adlandırılan 1. alt boyutu oluşturmuştur. Problem durumunu dikkatle inceleme, ayrıntılarla ilgilenme, analiz etme isteği altında hazırlanan maddeler ayrıntılara dikkat etme olarak adlandırılan 2. alt boyutu oluşturmuştur. Bir problem durumuna farklı çözüm yolu arama, olas1 sonuçlar üzerinde durma, kanıtlamaya yönelim altında hazırlanan maddeler bilgiyi çözümleme olarak adlandırılan 3. alt boyutu oluşturmuştur. Yeni fikir ve projeler üretme, tablolarla çalışmaktan zevk alma, kategorize etme, planlı çalışma altında hazırlanan maddeler çalışma stratejisi olarak 4. alt boyutu oluşturmuştur.

\section{Bulgular}

Araştırmanın bu bölümünde yapılan analizlere ilişkin bulgulara yer verilmiştir.

\subsection{Açımlayıcı Faktör Analizi}

Faktör analizi aynı yapıyı ya da niteliği ölçen değişkenleri bir araya toplayarak ölçmeyi az sayıda faktör ile açıklamayı amaçlayan bir istatistiksel tekniktir (Büyüköztürk, 2017). Eğer değişkenler arası ilişkiler sorgulanarak, yeni bir yap1 konmaya çalış1lıyorsa bu tür faktör analizine açımlayıcı faktör analizi denir (Can, 2017). Hazırlanan ölçeğin yapısal özelliklerini belirleyebilmek için açımlayıcı faktör analizi yapılmıştır.

Yapılan ön analizler sonucunda; örneklem oluşturma uygunluğu için, KMO (Kaiser Meyer - Olkin) değerine bakılmış ve 0.921 hesaplanmıştır. Örneklem oluşturma uygunluğu için bu değerin 0,7'den büyük olması istenir. Ölçeğin bütünlüğü için bakılan Barlett testi sonucu ise anlamlı çıkmıştır $[\mathrm{p}=0.000, \mathrm{p}<0.050]$. Ölçeğin bütünlüğü için bu değerin anlamlı çıkması istenir. Faktör analizi sırasında, çıkarılan maddelerden sonra KMO (Kaiser - Meyer - Olkin) değeri 0.897 'e düşmüştür. Yapılan ilk analiz ve son analizlerdeki KMO ve Barlett testi sonuçları tablo 6'da verilmiştir.

Tablo 6. İlk analiz ve son analiz KMO ve Barlett Testi sonuçları

\begin{tabular}{cccccc}
\hline \multicolumn{3}{c}{ İlk Analiz Sonuçları } & \multicolumn{3}{c}{ Son Analiz Sonuçları } \\
\hline \multicolumn{2}{c}{ Kaiser-Meyer-Olkin değeri } & 0.921 & Kaiser-Meyer-Olkin değeri & 0.897 \\
\hline Barlett & Approx. Chi-Sguare & 5409.476 & Barlett & Approx. Chi-Sguare & 2916.337 \\
Testi & Df & 741 & Testi & df & 276 \\
& Sig. & 0.000 & & Sig. & 0.000 \\
\hline
\end{tabular}

Ayrıca ön analizler sonucunda 9 adet faktör bulunmuştur. Bulunan 9 faktör toplam varyansın \%62.232'sini açıklamaktadır. Maddelerin faktör sayısına ilişkin çizgi grafiği aşağıda verilmiştir. 
Şekil 2. Lise Öğrencilerinin Analitik Düşünme Ölçeğinin Çizgi Grafiği

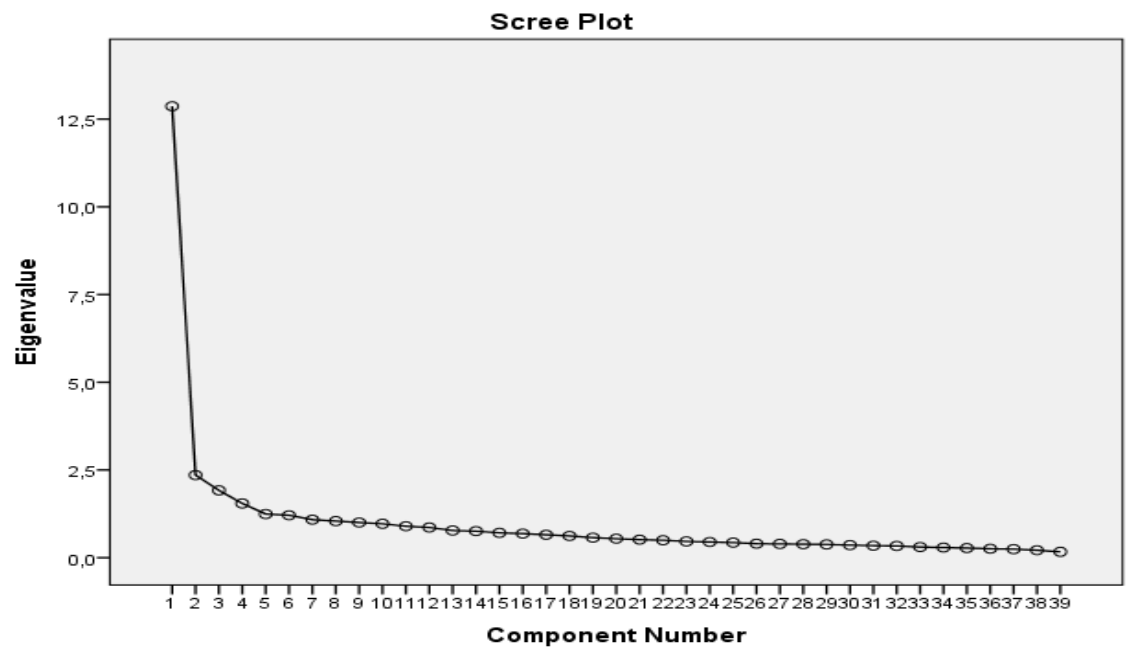

Analiz sürecinde dik döndürme yöntemlerinden yaygın olarak kullanılan varimax yöntemi kullanılmıştır. Dik döndürme yöntemi, maddelerin birbiriyle ilişkili bir durumu mevcut olmadığında ve verilerin kolay kontrol edilebilir birimlere ayırarak veri azaltmak durumu söz konusu olduğunda kullanılır (Ho, 2006; akt: Can, 2017). Analiz verilerine göre, ölçekteki bazı maddelerin birden fazla faktöre yüklendiği ve bazı maddelerin faktör yüklerinin düşük olduğu belirlenmiştir. Faktör yükleri, en büyük iki değeri arasındaki fark 0.10 'dan az ve faktör yükleri 0.40'dan küçük olan 18 madde adım adım faktör analizi yenilenerek ölçekten çıkarılmıştır (Büyüköztürk, Şekercioğlu ve Çokluk, 2018). Maddeler çıkarıldıktan sonra, faktör analizi sonucunda 4 alt boyut elde edilmiştir. Lise öğrencilerinin analitik düşünme ölçeğinin, varimax döndürme sonras1 birinci alt boyut \%19,324; ikinci alt boyut \%14,337; üçüncü alt boyut $\% 10,674$ ve dördüncü alt boyut \%10,117 olarak toplam varyansa katk1 sağlamıştır. Dört alt boyutta yer alan maddelerin toplam varyansı açıklama oranı \%54.452'dir. Scherer, Wiebe, Luther ve Adams'a (1998) göre, sosyal bilimlerde açılanan varyansın \% 40 ile \% 60 arasında olması yeterli olarak kabul edilir (akt: Tavşancıl, 2005). Lise öğrencilerinin, analitik düşünme ölçeğinin açıkladığı toplam varyans tablo 7'de verilmiştir. 
Tablo 7. Lise öğrencileri analitik düşünme ölçeğinin açıkladığı toplam varyans (total variance

\begin{tabular}{|c|c|c|c|c|c|c|c|c|c|}
\hline \multirow{2}{*}{ 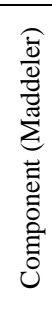 } & \multicolumn{3}{|c|}{$\begin{array}{c}\text { Initial Eigenvalues } \\
\text { (Öz Değerler) }\end{array}$} & \multicolumn{3}{|c|}{$\begin{array}{c}\text { Extraction Sums of Squared Load- } \\
\text { ings } \\
\text { (Karesi Alınan Yüklerin Toplam } \\
\text { Çıkarımı) }\end{array}$} & \multicolumn{3}{|c|}{$\begin{array}{l}\text { Rotation Sums of Squared Loadings } \\
\text { (Karesi Alınan Yüklerin Döndürme } \\
\text { Toplamı) }\end{array}$} \\
\hline & 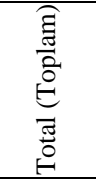 & 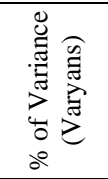 & 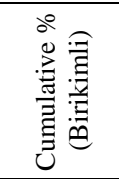 & 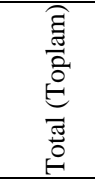 & 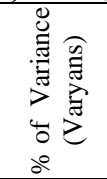 & 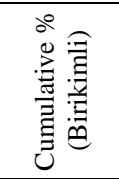 & 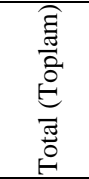 & 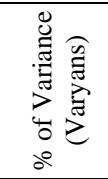 & 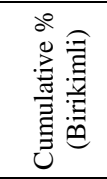 \\
\hline 1 & 8,008 & 33,366 & 33,366 & 8,008 & 33,366 & 33,366 & 4,638 & 19,324 & 19,324 \\
\hline 2 & 2,013 & 8,389 & 41,775 & 2,013 & 8,389 & 41,755 & 3,441 & 14,337 & 33,661 \\
\hline 3 & 1,686 & 7,023 & 48,778 & 1,686 & 7,023 & 48,778 & 2,562 & 10,674 & 44,335 \\
\hline 4 & 1,362 & 5,675 & 54,452 & 1,362 & 5,675 & 54,452 & 2,428 & 10,117 & 54,452 \\
\hline 5 & ,996 & 4,151 & 58,604 & & & & & & \\
\hline 6 & ,903 & 3,763 & 62,367 & & & & & & \\
\hline 7 & 841 & 3,505 & 65,871 & & & & & & \\
\hline 8 &, 788 & 3,283 & 69,154 & & & & & & \\
\hline 9 &, 748 & 3,115 & 72,269 & & & & & & \\
\hline 10 &, 704 & 2,932 & 75,201 & & & & & & \\
\hline 11 & 675 & 2,814 & 78,015 & & & & & & \\
\hline 12 & 610 & 2,544 & 80,559 & & & & & & \\
\hline 13 &, 579 & 2,412 & 82,971 & & & & & & \\
\hline 14 & ,503 & 2,094 & 85,065 & & & & & & \\
\hline 15 & 459 & 1,914 & 86,979 & & & & & & \\
\hline 16 & ,448 & 1,866 & 88,844 & & & & & & \\
\hline 17 & ,426 & 1,774 & 90,618 & & & & & & \\
\hline 18 & 405 & 1,687 & 92,306 & & & & & & \\
\hline 19 & 379 & 1,580 & 93,885 & & & & & & \\
\hline 20 & ,346 & 1,444 & 95,329 & & & & & & \\
\hline 21 & 331 & 1,380 & 96,709 & & & & & & \\
\hline 22 &, 282 & 1,175 & 97,884 & & & & & & \\
\hline 23 &, 272 & 1,113 & 99,017 & & & & & & \\
\hline 24 & 236 & ,983 & 100,000 & & & & & & \\
\hline
\end{tabular}

Tablo 8. Lise öğrencileri analitik düşünme ölçeğinin döndürülmüş bileşenler matrisi (rotated component matrix) tablosu

\begin{tabular}{|c|c|c|c|c|}
\hline \multirow{2}{*}{ Maddeler } & \multicolumn{4}{|c|}{ Component (Bileşenler) } \\
\hline & 1 & 2 & 3 & 4 \\
\hline A1 & ,734 & & & \\
\hline A2 & ,696 & & & \\
\hline A3 & 677 & & & \\
\hline A4 & 668 & & & \\
\hline A5 & 650 & & & \\
\hline A6 & 647 & & & \\
\hline A7 & ,608 & & & \\
\hline A8 & ,538 & & & \\
\hline A9 & ,485 & & & \\
\hline A10 & ,449 & & & \\
\hline $\mathrm{B} 1$ & & ,772 & & \\
\hline B2 & & ,768 & & \\
\hline B3 & & ,711 & & \\
\hline B4 & & 657 & & \\
\hline B5 & & ,652 & & \\
\hline B6 & & ,590 & & \\
\hline $\mathrm{C} 1$ & & & ,769 & \\
\hline $\mathrm{C} 2$ & & &, 711 & \\
\hline $\mathrm{C} 3$ & & & 685 & \\
\hline $\mathrm{C} 4$ & & & ,617 & \\
\hline D1 & & & & ,758 \\
\hline D2 & & & & ,731 \\
\hline D3 & & & & 676 \\
\hline D4 & & & & ,646 \\
\hline
\end{tabular}


Birden fazla faktörü bulunan ölçeklerde, varimax rotasyon tekniği kullanılması uygundur (Büyüköztürk, 2002). Ölçekte faktörlerin, aralarında ilişkisiz, bağımsız olduğu kabul edilerek varimax dik döndürme tekniği kullanılmıştır (Saraçl1, 2011). Tablo 8 incelendiğinde, döndürme sonrası 1. faktörde 10 maddenin, 2. faktörde 6 maddenin, 3. faktörde 4 maddenin ve 4. faktörde 4 maddenin bulunduğu görülmektedir. Faktör yükleri için, $0.30-0.60$ arası yük değerleri orta düzeyde büyüklükler olarak tanımlanırken, 0.60 ve üstü yük değerleri yüksek olarak tanımlanmaktadır (Büyüköztürk, 2002). Ölçekte yer alan 24 maddeye ilişkin faktör yük değerleri $0.449-0.772$ arasında değişmektedir. 1. faktörde $0.449-0.734,2$. faktörde yük değerleri $0.590-0.772,3$. faktörde yük değerleri $0.617-0.769$ ve 4 . faktörde yük değerleri 0.646 - 0.758 arasında değişmektedir. Ölçekteki yük değerleri incelendiğinde genel olarak yüksek durumda olduğu söylenebilir.

Yapılan analizler sonucunda ölçeğin dört alt boyutlu olduğu ve bu durumun ölçeğin hazırlanması aşamalarında görüşme sorularına alınan cevaplar ve literatür taraması sonucu oluşturulan alt boyutları yansıttığı görülmektedir.

Ölçeğin geliştirilmesi aşamasında araştırmaya katılan öğrencilerden üst ve alt grupta yer alanların cevapları ilişkisiz t testi ile karşılaştırılmıştır. Faktör analizi sonucunda belirlenen tüm maddelerin alt ve üst grup farkının anlamlı olduğu tespit edilmiştir.

Tablo 9. Lise öğrencileri analitik düşünme ölçeğinin 1. alt boyutuna (bilgiyi özümseme) ait geçerlik-güvenirlik analizi sonuçları

\begin{tabular}{|c|c|c|c|c|c|c|}
\hline & Maddeler & $\begin{array}{c}\text { Varimax } \\
\text { Faktör Yükü }\end{array}$ & $\begin{array}{c}\text { Ortak Faktör } \\
\text { Varyans1 }\end{array}$ & $\begin{array}{l}\text { Madde Toplam } \\
\text { Korelasyon Katsayis1 }\end{array}$ & $\mathrm{t}$ & $\mathrm{p}$ \\
\hline \multirow{10}{*}{ 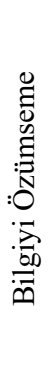 } & A1 & ,734 & ,616 & 624 & $-9,82$ & 0,00 \\
\hline & $\mathrm{A} 2$ & ,696 &, 537 & ,549 & $-8,41$ & 0,00 \\
\hline & A3 & 677 & 613 & 630 & $-10,28$ & 0,00 \\
\hline & A4 & 668 & ,460 & ,444 & $-6,91$ & 0,00 \\
\hline & A5 & 650 & ,503 & ,576 & $-9,30$ & 0,00 \\
\hline & A6 & 647 & ,494 & ,543 & $-8,53$ & 0,00 \\
\hline & A7 & 608 & 477 & ,544 & $-9,99$ & 0,00 \\
\hline & A8 &, 538 &, 340 & 442 & $-7,78$ & 0,00 \\
\hline & A9 & ,485 & 377 &, 543 & $-10,15$ & 0,00 \\
\hline & A10 & ,449 & ,360 & ,535 & $-8,13$ & 0,00 \\
\hline
\end{tabular}

Tablo 10. Lise öğrencileri analitik düşünme ölçeğinin 2. alt boyutuna (ayrıntılara dikkat etme) ait geçerlik-güvenirlik analizi sonuçları

\begin{tabular}{|c|c|c|c|c|c|c|}
\hline & Maddeler & $\begin{array}{c}\text { Varimax } \\
\text { Faktör Yükü }\end{array}$ & $\begin{array}{l}\text { Ortak Faktör } \\
\text { Varyansı }\end{array}$ & $\begin{array}{c}\text { Madde Toplam } \\
\text { Korelasyon Katsayıs1 }\end{array}$ & $\mathrm{t}$ & $\mathrm{p}$ \\
\hline \multirow{6}{*}{ 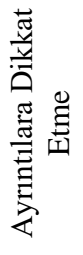 } & B1 & ,772 & ,661 &, 520 & $-10,43$ & 0,00 \\
\hline & B2 & ,768 & ,678 & ,558 & $-11,27$ & 0,00 \\
\hline & B3 & ,711 & ,597 & ,539 & $-10,84$ & 0,00 \\
\hline & B4 & 657 &, 556 & ,554 & $-11,77$ & 0,00 \\
\hline & B5 & 652 & ,556 &, 531 & $-9,63$ & 0,00 \\
\hline & B6 & 590 & 451 &, 528 & $-10,71$ & 0,00 \\
\hline
\end{tabular}

Tablo 11. Lise öğrencileri analitik düşünme ölçeğinin 2. alt boyutuna (bilgiyi çözümleme) ait geçerlik-güvenirlik analizi sonuçları

\begin{tabular}{|c|c|c|c|c|c|c|}
\hline & Maddeler & $\begin{array}{l}\text { Varimax } \\
\text { Faktör Yükü }\end{array}$ & $\begin{array}{l}\text { Ortak Faktör } \\
\text { Varyans1 }\end{array}$ & $\begin{array}{l}\text { Madde Toplam } \\
\text { Korelasyon Katsayısı }\end{array}$ & $\mathrm{t}$ & $\mathrm{p}$ \\
\hline \multirow{4}{*}{ 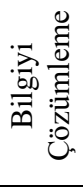 } & $\mathrm{C} 1$ & ,769 & ,686 & ,537 & $-10,12$ & 0,00 \\
\hline & $\mathrm{C} 2$ & ,711 & ,615 & ,480 & $-9,11$ & 0,00 \\
\hline & C3 & ,685 & ,577 &, 504 & $-8,55$ & 0,00 \\
\hline & $\mathrm{C} 4$ & 617 & ,579 & ,568 & $-10,33$ & 0,00 \\
\hline
\end{tabular}


Tablo 12. Lise öğrencilerinin analitik düşünme ölçeğinin 2. alt boyutuna (çalışma stratejisi) ait geçerlik-güvenirlik analizi sonuçları

\begin{tabular}{|c|c|c|c|c|c|c|}
\hline & Maddeler & $\begin{array}{c}\text { Varimax } \\
\text { Faktör Yükü }\end{array}$ & $\begin{array}{c}\text { Ortak Faktör } \\
\text { Varyansı }\end{array}$ & $\begin{array}{c}\text { Madde Toplam } \\
\text { Korelasyon Katsayıs1 }\end{array}$ & $\mathrm{t}$ & $\mathrm{p}$ \\
\hline \multirow{4}{*}{ 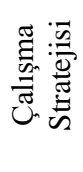 } & D1 & ,769 & ,686 & ,537 & $-10,12$ & 0,00 \\
\hline & D2 & ,711 & ,615 & ,480 & $-9,11$ & 0,00 \\
\hline & D3 & 685 & ,577 & ,504 & $-8,55$ & 0,00 \\
\hline & D4 & ,617 & ,579 & ,568 & $-10,33$ & 0,00 \\
\hline
\end{tabular}

Her bir faktöre ve toplama ait iç tutarlık katsayıları hesaplanmış ve yüksek bulunmuştur. Lise öğrencilerine uygulanan analitik düşünme ölçeğinden elde edilen puanlar büyükten küçüğe doğru sıralanmış ve sıralanmış puanlara göre üst $\% 27^{\prime} l i k(n=80)$ ve alt $\% 27^{\prime}$ lik $(n=80)$ iki grup oluşturulmuştur. Tablo 9, 10, 11 ve 12 incelendiğinde, ölçekte yer alan her bir maddenin puanlarına göre belirlenen üst \%27'lik ve alt \%27'lik gruplar arasında anlamlı bir fark olup olmadığını belirlemek için yapılan bağımsız örneklem t-testi sonucunda tüm maddelerde anlamlı farklılığın olduğu görülmektedir $(\mathrm{p}<.05)$. Her faktörün açıkladığı varyans ve alfa katsayıları tablo 13'de verilmiştir.

Tablo 13. Lise ögrencilerinin analitik düşünme ölçeğinin ve alt faktörlerinin açıladığı madde sayısı, varyans oranları ve iç tutarlılık katsayıları

\begin{tabular}{lccc}
\hline \multicolumn{1}{c}{ Faktörler } & Madde Sayıs1 & Açıkladı̆̆ Varyans & Alfa \\
\hline Faktör 1(bilgiyi özümseme) & 10 & $\% 19,32$ & 0,867 \\
Faktör 2 (ayrıntılara dikkat etme) & 6 & $\% 14,33$ & 0,840 \\
Faktör 3(çözümleme) & 4 & $\% 10,67$ & 0,774 \\
Faktör 4(çalışma stratejisi) & 4 & $\% 10,11$ & 0,741 \\
\hline \multicolumn{1}{c}{ Toplam } & 24 & $\% 54,45$ & 0,908 \\
\hline
\end{tabular}

Tablo 13 incelendiğinde, her bir faktörün açıkladığı varyans oranı sırasıyla yüzde 19.32, yüzde 14.33, yüzde 10.67 ve yüzde 10.11 olmak üzere toplam yüzde 54.45'tür. 1. faktörün (Bilgiyi Özümseme) alfa katsayısı 0.867, 2. faktörün (Ayrıntılara Dikkat Etme) alfa katsayıs1 0.840, 3. faktörün (Bilgiyi Çözümleme) alfa katsayısı 0.774, 2. faktörün (Çalışma Stratejisi) alfa katsayıs1 0.741 'tir. Ölçeğin toplam alfa değeri ise 0.908 'dir. Bu durumda lise öğrencilerinin analitik düşünme ölçeğinin oldukça yüksek güvenirliğe sahip olduğu söylenebilir.

Tablo 14. Lise öğrencilerinin analitik düşünme ölçeğinin iç tutarlılık katsayıları (Split-half)

\begin{tabular}{|c|c|c|c|c|c|c|}
\hline \multicolumn{2}{|c|}{ Cronbach’ Alpha } & \multirow{2}{*}{$\mathrm{N}$} & \multirow{2}{*}{$\begin{array}{c}\text { Correlation } \\
\text { Between Forms }\end{array}$} & \multicolumn{2}{|c|}{ Spearman-Brown Coefficient } & \multirow{2}{*}{$\begin{array}{c}\text { Guttman Split- } \\
\text { Half } \\
\text { Coefficient }\end{array}$} \\
\hline Part1 & Part2 & & & $\begin{array}{l}\text { Equal } \\
\text { Length }\end{array}$ & $\begin{array}{l}\text { Unequal } \\
\text { Length }\end{array}$ & \\
\hline ,869 &, 847 & 24 & ,644 &, 783 &, 783 & ,783 \\
\hline
\end{tabular}

Ölçeğin Cronbach Alfa güvenirlik katsayılarının yanı sıra ikiye bölme (Split-half) yöntemi ile de güvenirliği araştırılmıştır. Ölçek iki gruba ayrılmıştır. Güvenilirlik kat sayıları gruplar için sırasıyla .869 ve .847 olarak bulunmuştur. Her iki grubun güvenirlik katsayılarının birbirine yakın olduğu ve iyi düzeyde olduğu söylenebilir. Bu değerler maddelerin birbirini izleyen nitelikte düzenlendiğini ifade etmektedir. İki grup arasında pozitif yönde ve orta düzeyde doğrusal bir ilişki bulunmuştur (r: .644). Ayrıca Guttman ve Spearman-Brown katsayıları da Split-half yöntemi ile yapılan güvenirlik analiz sonuçlarında yer almıştır (Guttman: .783; Equal-length: .783; Unequal-length: .783). Sonuç olarak elde edilen veriler değerlendirildiğinde, lise öğrencilerinin analitik düşünme düzeylerini belirlemek için geliştirilen ölçeğin güvenirliğinin yüksek olduğu söylenebilir. 
Tablo 15. Lise öğrencilerinin analitik düşünme ölçeğinin alt faktörlerine ilişkin ortalama ve

\begin{tabular}{ccccccc}
\multicolumn{7}{c}{ korelasyon katsay1lar1 } \\
\hline Faktörler & $\mathrm{N}$ & $\mathrm{X}$ & 1.Faktör & 2.Faktör & 3.Faktör & 4.Faktör \\
\hline 1.Faktör & 297 & 39,85 & - & - & - & - \\
2.Faktör & 297 & 21,63 &, 524 & - & - & - \\
3.Faktör & 297 & 15,25 &, 574 &, 484 & - & - \\
4.Faktör & 297 & 13,77 &, 432 &, 400 &, 340 & - \\
\hline
\end{tabular}

Tablo 15 incelendiğinde, lise öğrencilerinin analitik düşünme ölçeğiyle ilgili korelasyon katsayısı, faktörler arasında anlamlı ve orta düzeyde ilişkinin olduğunu göstermektedir.

\subsection{Doğrulayıcı Faktör Analizi}

Bu bölümde açımlayıcı faktör analizi yapılan Analitik Düşünme Ölçeği birinci ve ikinci düzey doğrulayıcı faktör analizi sonuçlarına yer verilmiştir.

\subsubsection{Birinci Sıralı Doğrulayıcı Faktör Analizi}

DFA analizi doğrultusunda, GFI'nin 0.86, AGFI' nin 0.83, SRMR uyum indeksinin 0.058, NNFI'nın 0.96, CFI'nın 0.96 olduğu sonucuna varılmıştır. GFI, AGFI, NNFI ve CFI indekslerinin 0.90 'dan daha fazla olması, RMR değerinin ise 0.08 'den daha düşük olması iyi uyum olduğunu göstermektedir (Hooper, Coughlan ve Mullen, 2008; Ulrich ve Lehrmann, 2008; Jöreskog ve Sörbom, 1993; Tabachinck ve Fidell, 2001; Brown, 2006). Bu araştırma kapsamında gerçekleştirilen analizler doğrultusunda ortaya çıkan modele ait grafik Şekil 3' de verilmiştir. 
Şekil 3. Lise Öğrencileri analitik düşünme ölçeği için birinci sıralı dfa modeli ve madde faktör bağıntıları

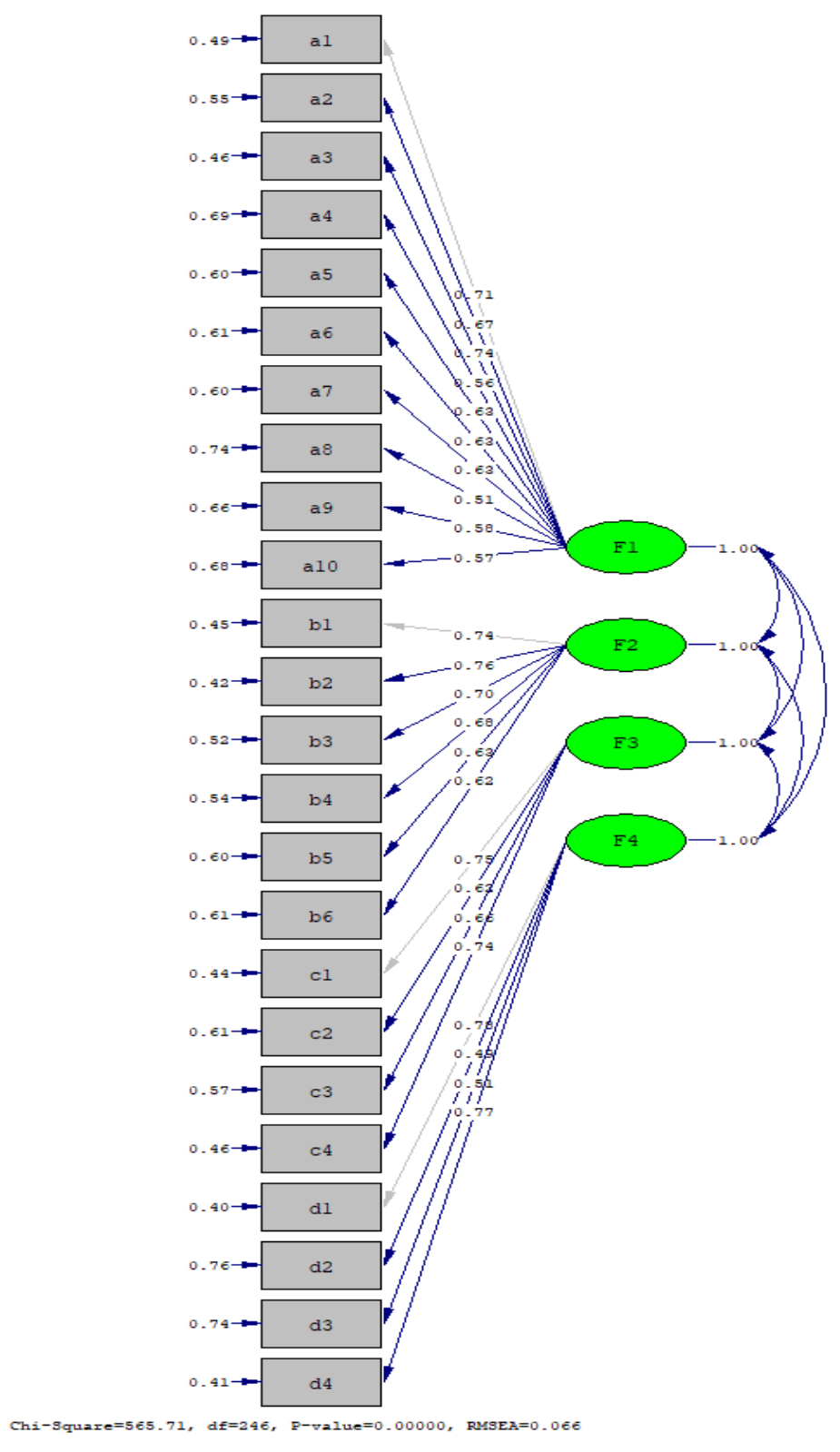

\subsection{2. İkinci Stralı DFA ve Faktöriyel Geçerlik}

Yapılan analizler doğrultusunda lise öğrencileri için analitik düşünme ölçeği dört alt boyutunun ayrı ayrı değerlendirilebileceği sonucuna varılmıştır. Ancak lise öğrencileri için analitik düşünme ölçeği, alt ölçekleri ile tek bir genel yapıyı oluşturması ve toplam bir analitik düşünme puanı vermesi de beklenmektedir. Bu amaçla, lise öğrencileri için analitik düşünme ölçeğinin alt ölçekleri ile tek bir analitik düşünme yapısına yönelme durumu ve faktöriyel geçerliğinin belirlenmesi için ikinci sıralı DFA (Seconder CFA) yapılmıştır (Byrne, 1998). Yine lise öğrencileri için analitik düşünme ölçeği dört alt boyutu ile tek analitik düşünme ortak yapısını oluşturduğunu test etmek için kurulan model DFA ile test edilmiştir. İkinci sıralı DFA sonuçları incelendiğinde, lise öğrencileri için analitik düşünme ölçeği 24 maddesinin, faktör yüklerinin 0.49 ile 0.76 aralığında değer aldığı sonucuna ulaşılmıştır. Grafikte yer alan t değerleri incelenmiş ve uyumsuz bir değere rastlanmamıştır. Uyumsuz bir değerin olmaması, örtük değişkenler ve değişkenler arasındaki ilişkinin anlamlı olduğunu göstermektedir(p<0,05) 
(Şimşek, 2007). Yapılan ikinci sıralı DFA sonucu, lise öğrencileri için analitik düşünme ölçeğinin 24 maddesi alt boyutların yanı sıra tek bir genel analitik düşünme yapısını da ölçebileceğini göstermektedir. Yapılan analizlerin ardından ortaya çıkan grafik Şekil 4' de verilmiştir.

Şekil 4. Lise öğrencileri analitik düşünme ölçeği ikinci sıralı DFA modeli ve madde faktör bağıntıları

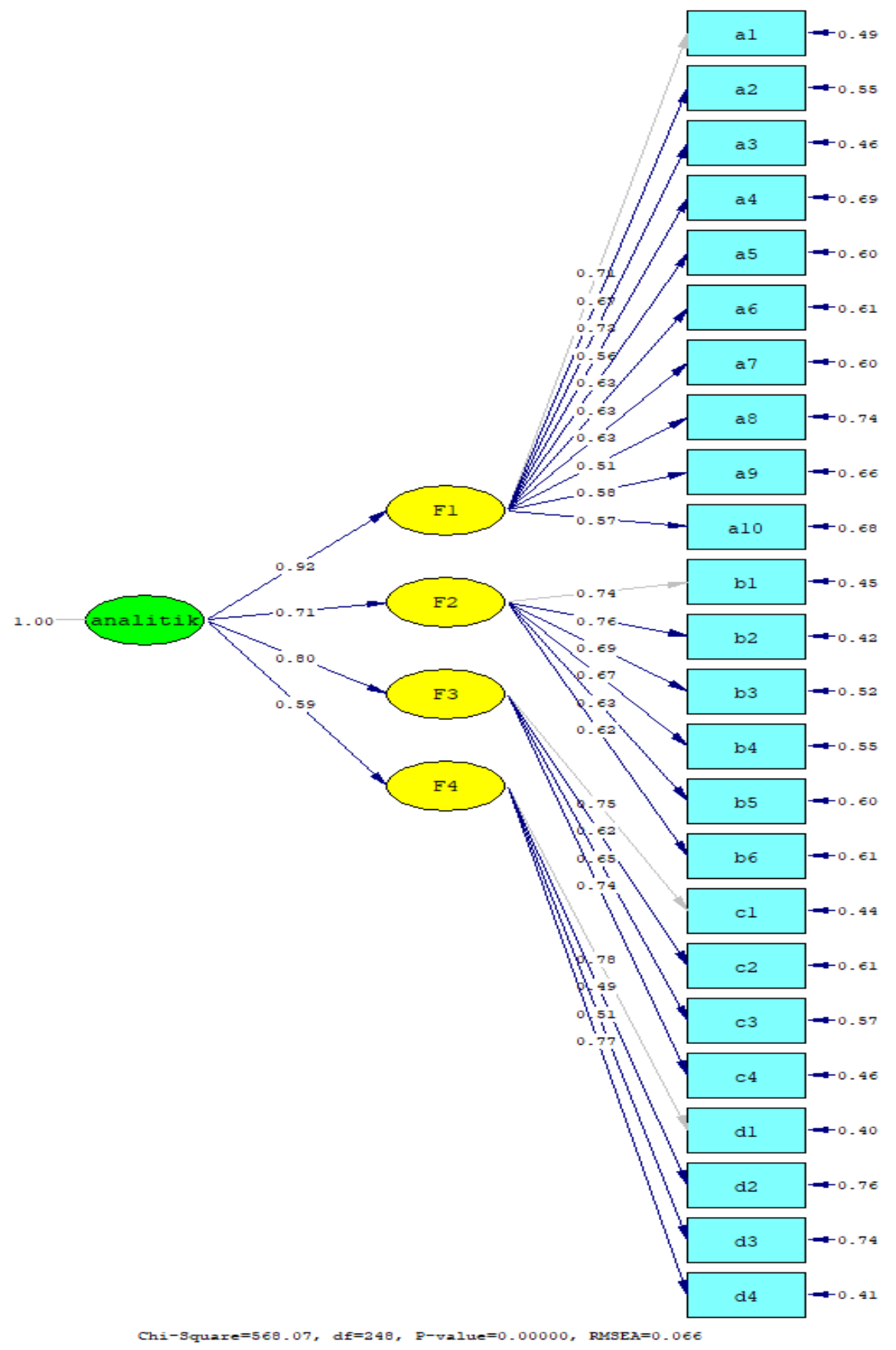

(Boyutlar; Bilgiyi Özümseme, Ayrıntılara Dikkat Etme, Çözümleme ve Çalışma Stratejisi)

Lise öğrencileri analitik düşünme ölçeği için yapılan ikinci düzey DFA analizinde $\mathrm{x}^{2}$ değerinin 565.71, serbestlik derecesinin 246 olarak bulunmuştur. Bu iki veri birbirine 
bölündüğünde $\mathrm{x}^{2} / \mathrm{sd}(635.14 / 249)$ sonuç 2.29 elde edilmiştir. Tablo 16 incelendiğinde elde edilen değerin kabul edilebilir uyum gösterdiği söylenebilir (Kline, 2011).

Tablo 16. Analitik düşünme ölçeği ölçüm modeline ait hesaplanan uyum indeksleri

\begin{tabular}{ccccc}
\hline & Uyum İndeksleri & Mükemmel Uyum Ölçütleri & $\begin{array}{c}\text { Kabul Edilebilir Uyum } \\
\text { Ölçütleri }\end{array}$ & $\begin{array}{c}\text { Hesaplanan Modele } \\
\text { Ait Uyum İndeksleri }\end{array}$ \\
\hline 1 & ${ }^{1} \mathrm{X}^{2} / \mathrm{sd}$ & $0 \leq \mathrm{x}^{2} / \mathrm{sd} \leq 2$ & $2 \leq \mathrm{x} / \mathrm{sd} \leq 3$ & 2.29 \\
2 & ${ }^{2} \mathrm{AGFI}$ & $.90 \leq \mathrm{AGFI} \leq 1.00$ & $.85 \leq \mathrm{AGFI} \leq .90$ & .83 \\
3 & ${ }^{3} \mathrm{GFI}$ & $.95 \leq \mathrm{GFI} \leq 1.00$ & $.90 \leq \mathrm{GFI} \leq .95$ & .86 \\
4 & ${ }^{3} \mathrm{CFI}$ & $.95 \leq \mathrm{CFI} \leq 1.00$ & $.90 \leq \mathrm{CFI} \leq .95$ & .96 \\
5 & ${ }^{3} \mathrm{NFI}$ & $.95 \leq \mathrm{NFI} \leq 1.00$ & $.90 \leq \mathrm{NFI} \leq .95$ & .93 \\
6 & ${ }^{3} \mathrm{NNFI}(\mathrm{TLI})$ & $.95 \leq \mathrm{NNFI}(\mathrm{TLI}) \leq 1.00$ & $.90 \leq \mathrm{NNFI}(\mathrm{TLI}) \leq .95$ & .96 \\
7 & ${ }^{3} \mathrm{RFI}$ & $.95 \leq \mathrm{RFI} \leq 1.00$ & $.90 \leq \mathrm{RFI} \leq .95$ & .92 \\
8 & ${ }^{3} \mathrm{IFI}$ & $.95 \leq \mathrm{IFI} \leq 1.00$ & $.90 \leq \mathrm{IFI} \leq .95$ & .96 \\
9 & ${ }^{4} \mathrm{RMSEA}$ & $.00 \leq \mathrm{RMSEA} \leq .05$ & $.05 \leq \mathrm{RMSEA} \leq .08$ & .06 \\
10 & ${ }^{4} \mathrm{SRMR}$ & $.00 \leq \mathrm{SRMR} \leq .05$ & $.05 \leq \mathrm{SRMR} \leq .10$ & .05 \\
11 & ${ }^{5} \mathrm{PNFI}$ & $.95 \leq \mathrm{PNFI} \leq 1.00$ & $.50 \leq \mathrm{PNFI} \leq .95$ & .83 \\
12 & ${ }^{6} \mathrm{PGFI}$ & $.95 \leq \mathrm{PGFI} \leq 1.00$ & $.50 \leq \mathrm{PGFI} \leq .95$ & .71 \\
\hline
\end{tabular}

Kaynaklar: ${ }^{1}$ (Kline, 2011), ${ }^{2}$ (Schermelleh-Engel ve Moosbrugger, 2003), ${ }^{3}$ (Baumgartner ve Homburg, 1996; Bentler, 1980; Bentler ve Bonnet, 1980; Mars, Hau, Artelt, Baumert ve Peschar, 2006), ${ }^{4}$ (Browne ve Cudeck, 1993), ${ }^{5}$ (Hu ve Bentler, 1999), ${ }^{6}($ Meyers, Gamst ve Guarino, 2006).

Lise öğrencileri için analitik düşünme ölçeğinin dört alt boyutu (bilgiyi özümseme, ayrıntılara dikkat etme, çözümleme ve çalışma stratejisi) ele alındığında tek bir analitik düşünme temel yapısını oluşturduğunu kontrol etmek amaciyla uygulanan model DFA aracılığıyla test edilmiştir. Yapılan analiz sonucunda $\mathrm{NNFI}=0,96$; $\mathrm{CFI}=0,96$; $\mathrm{IFI}=0,96$ ve RMSEA $=0.06$ uyum indeksleri olarak elde edilmiştir. Tablo 16'da gösterilen uyum indeksleri ile elde edilen uyum indeksleri karşılaştırılmıştır. Bu karşılaştırma işlemi doğrultusunda ölçek maddelerinin ilgili alt boyutların yanı sıra temel analitik düşünme yapısıyla olan modelinin doğrulandığı sonucuna varılmıştır.

\section{Tartışma}

Literatür taraması sonucunda Umay ve Arıl (2011), bütüncül ve analitik düşünme stillerinin matematik problemlerini çözebilme düzeyleri ve bu stillerin seçilen çözüm yolları üzerinde nasıl bir etkisi olduğunu incelemeyi amaçlamışlardır. Sebetçi ve Aksu (2014), mantıksal ve analitik düşünme becerilerinin programlama dilleri başarısı üzerindeki etkisinin belirlenmesini amaçlamışlardır. Akkuş-Çakır ve Senemoğlu (2016), üniversite öğrencilerinin analitik düşünme beceri düzeylerini incelemek ve bu becerilerin gelişimini etkileyen etmenleri belirlemeyi amaçlamışlardır. Bahsedilen araştırmalar göz önüne alındığında analitik düşünme düzeyleri üzerine farklı yöntem ve teknikte araştırmalar yapılmış fakat bu alandaki ölçeklerin sınırlılığı sebebiyle yapılan araştırmalar nicel olarak desteklenemediği söylenebilir.

Geliştirilen ölçek, istatistiksel analiz sonuçlarına göre, alan yazında lise öğrencilerinin analitik düşünme düzeylerini ölçmeye yönelik geçerli ve güvenilir ölçek olarak kullanılabilecek niteliktedir. Literatürde yer alan araştırmaların çoğunun, genellikle farklı alanlarda durum saptamaya yönelik olduğu veya ölçek olarak farklı kültürlerde geliştirilmiş yabancı kökenli ölçeklerin tercih edildiği görülmektedir. Bu çalışmada 21 . yy becerileri arasında yer alan ve son yıllarda problem çözme alanında yoğun kullanılması önerilen düşünme türlerinden biri olan analitik düşünmeye ilişkin durum tespitinin yapılabilmesi açısından önemli olan "Analitik düşünme Ölçeği” geliştirilmiştir. Lise öğrencilerinin analitik düşünme düzeylerinin belirlenmesi açısından kullanılabilir düzeyde bir ölçek olarak değerlendirilebilir. Ölçek maddelerinden elde edilen toplam puan, lise öğrencilerinin analitik düşünme düzeyleri belirlemek amacıyla yapılan gözlem sonuçlarıyla da örtüşme durumları incelenerek öğrencilerin analitik düşünme düzeylerine ilişkin güvenilir kararlar verilebilir. 


\section{Sonuç ve Öneriler}

$\mathrm{Bu}$ araştırmada lise öğrencilerinin analitik düşünme düzeylerini belirlemek amaciyla 5'li likert tipinde "Lise Öğrencileri Analitik Düşünme Ölçeği”" geliştirilmiştir. Başlangıçta 39 maddeden oluşan deneme ölçeğine yönelik yapılan analizler sonunda ölçekten 15 madde çıkarılmıştır. 324 lise öğrencisine uygulanan bu ölçek dört faktör ve 24 maddeden oluşmaktadır. Ölçek maddelerine uygulanan korelasyon tekniği ile elde edilen madde toplam korelasyon sonuçları, alt üst grup ortalamaları farkına dayalı elde edilen t testi sonuçları, açımlayıcı ve doğrulayıcı faktör analizi sonuçları 24 maddelik lise öğrencileri analitik düşünme ölçeğinin uygun düzeylerde sonuçlara sahip alt boyutlarıyla birlikte analitik düşünmeyi ölçmeye uygun maddelerden oluştuğunu göstermektedir. Lise öğrencileri analitik düşünme ölçeğine ilişkin yapılan geçerlik ve güvenirlik analizleri sonucunda, geçerli ve güvenilir bir ölçme aracı olduğu kabul edilebilir sonuçlara ulaşılmıştır. 24 maddeden oluşan ölçeğin geneli için Cronbach alpha katsayıs1 0.908 olarak hesaplanmıştır. Ölçekten alınabilecek minimum puan 24, maksimum puan 120 'dir. Birinci faktör bilgiyi özümseme, ikinci faktör ayrıntılara dikkat etme, üçüncü faktör bilgiyi çözümleme ve dördüncü faktör çalışma stratejisi şeklinde isimlendirilmiştir. Açımlayıcı faktör analizinden elde edilen yapıyı doğrulamak amacıyla doğrulayıcı faktör analizi uygulanmıştır. Yapılan analizler sonucunda elde edilen uyum indeksleri, açımlayıcı faktör analizi ile elde edilen yapının doğrulandığını göstermektedir.

Hair, Anderson, Tatham ve Black (1998)'e göre t değerlerinin $-1,96$ ve $+1,96$ değerleri arasında olduğu görülerek veri setinde uyumsuz bir değer görülmemiştir.

$\mathrm{Bu}$ araştırmaya ek olarak aşağıdaki öneriler sunulmaktadır.

- Geliştirilen ölçekle lise öğrencilerinin analitik düşünme düzeyleri belirlenmesi üzerine uygun çalışmalar yapılabilir,

- Öğrenciler ile yapılacak gözlem ve görüşmeler sonucunda analitik düşünme düzeyini olumlu ya da olumsuz yönde etkileyen faktörler hakkında araştırmalar yapilabilir.

\section{Kaynakça}

Akkuş-Çakır, N. ve Senemoğlu, N. (2016). Yükseköğretimde analitik düşünme becerileri. Kastamonu Eğitim Dergisi, 24(3), 1487-1502.

Baumgartner, H. ve Homburg, C. (1996). Applications of structural equation modeling in marketing and consumer research: A review. International Journal of Research In Marketing, 13(2), 139-161.

Bentler, P. M. (1980). Multivariate analysis with latent variables: Causal Modeling. Annual Review of Psychology, 31(1), 419-456.

Bentler, P. M. ve Bonett, D. G. (1980). Significance tests and goodness of fit in the analysis of covariance structures. Psychological Bulletin, 88(3), 588.

Brown, T. A. (2006). Confirmatory factor analysis for applied research. New Jersey: Guilford Publications.

Browne, M. W. ve Cudeck, R. (1993). Alternative ways of assessing model fit. Sage Focus Editions, (154), 136-136.

Byrne, B. M. (1998). Structural equation modeling with lisrel, prelis, and simplis: Basic concepts, applications and programming. Mahwah, New Jersey: Lawrence Erlbaum Associates.

Büyüköztürk, Ş. (2002). Faktör analizi: Temel kavramlar ve ölçek geliştirmede kullanımı. Kuram ve Uygulamada Eğitim Yönetimi Dergisi, (32, )470-483. 
Büyüköztürk, Ş. (2017). Sosyal bilimler için veri analizi el kitabı. (23.Baskı). Ankara: Pegem Yayınevi.

Can, A. (2017). Spss ile bilimsel araştırma sürecinde nicel veri analizi (5.Baskı). Ankara: Pegem Akademi.

Creswell, J. W. ve Plano Clark, V. L. (2011). Designing and conducting mixed methods research (2nd Edition). Thousand Oaks: Sage.

Creswell, J. W. (2013). Nitel araştırma yöntemleri beş yaklaşıma göre nitel araştırma ve araştırma deseni (3. Baskıdan Çeviri). (Çeviri Editörleri: M. Bütün ve S.B. Demir). Ankara: Siyasal Yayın Dağıtım.

Cüceloğlu, D. (1999). İyi düşün doğru karar ver. İstanbul: Sistem Yayınc1lık.

Çelik, H., Gürpınar, C., Başer, N., ve Erdoğan, S. (2015). Öğrencilerin analitik düşünme becerisinin gelişimi üzerine fen bilgisi öğretmenlerinin görüşleri. Akademik Platform, 396408

Çokluk, Ö. Şekercioğlu, G., ve Büyüköztürk, Ş. (2018). Sosyal bilimler için çok değişkenli istatistik: SPSS ve LISREL uygulamaları. Ankara: Pegem Akademi.

Dewey, R. A. (2007). Psychology: an introduction (http://www.intropsych.Com)

Fidan, M. (2018). Nitel araştırmalar ve düşünümsellik: Bir kritik analitik düşünme pratiği. Akademik Platform Ĕgitim ve Değişim Dergisi, 1(2), 23-35.

Fraenkel, J. R., Wallen, N. E., ve Hyun, H. H. (2011). How to design and evaluate research in education. New York: McGraw-Hill Humanities/Social Sciences/Languages.

Güneş, F. (2012). Öğrencilerin düşünme becerilerini geliştirme. TÜBAR (XXXII), 127-146.

Haciömeroğlu, E. S., Haciömeroğlu, G., Güzel, E., ve Kula, S. (2014). Türev ve İntegral problemlerinin çözümünde görsel, analitik ve harmonik çözüm tercihleri. Dicle Üniversitesi Ziya Gökalp Ë̆itim Fakültesi Dergisi, (22), 108-119.

Hooper, D., Coughlan, J. ve Mullen, M. (2008). Structural equation modelling: Guidelines for determining model fit. Electronic Journal of Business Research Methods, 6(1), 53-60.

Hu, L. T. ve Bentler, P. M. (1999). Cutoff criteria for fit indexes in covariance structure analysis: Conventional criteria Versus new alternatives. Structural Equation Modeling: A Multidisciplinary Journal, 6(1), 1-55.

Jöreskog, K. G. ve Sörbom, D. (1993). Lisrel 8: Structural equation modeling with the simplis Command Language. Lincolnwood, IL: Scientific Software International.

Kavak, B., Kazancı Sunaoğlu, Ş. ve Taner, N. (2017). Yeniliği benimseyen kategorilerinin bütüncül ve analitik düşünme açısından farklılıkları: Akıllı telefonlar için bir inceleme. Pazarlama ve Pazarlama Araştırmaları Dergisi, (20), 179-200

Kline, R. B. (2011). Principles and practice of structural equation modeling. New York, NY: Guilford Press.

Malloy, C. E. ve Jones, M. G. (1998). An investigation of African American students' mathematical problem solving. Journal for Research In Mathematics Education, 2(29), 143163.

Meyers, L. S., Gamst, G. ve Guarino, A. J. (2006). Data screening. Applied Multivariate Research-Design and Interpretation, (1), 43-73.

Ocak, G., Ocak, İ. ve Saban, A. (2013). Sınıf öğretmenlerinin fen ve teknoloji derslerindeki yansitıcı düşünme eğilimlerinin değerlendirilmesi. Uludă̆ Eğitim Fakültesi Dergisi, 25(1), $161-184$. 
Parlar, H. (2016). Sınıf öğretmenlerinin kritik ve analitik düşünme becerilerinin-eğilimlerinin incelemesi: İstanbul Ümraniye örneği, Istanbul Ticaret Üniversitesi Sosyal Bilimleri Dergisi, (26), 1-28.

Saraçl1, S. (2011). Faktör analizinde yer alan döndürme metotlarının karşılaştırılmalı incelenmesi üzerine bir uygulama. Düzce Üniversitesi Să̆llk Bilimleri Enstitüsü Dergisi. $1(3), 22-26$.

Schermelleh-Engel, K., Moosbrugger, H. ve Müller, H. (2003). Evaluating the fit of structural equation models: Tests of significance and descriptive goodness-of-fit measures. Methods of Psychological Research Online, 8(2), 23-74.

Sebetçi, Ö. ve Aksu, G. (2014). Öğrencilerin mantıksal ve analitik düşünme becerilerinin programlama dilleri başarısına etkisi. Journal of Educational Sciences \& Practices, 13(25), 65-83.

Sternberg R J. (2006). The Rainbow Project: Enhancing the SAT through assessments of analytical, practical, and creative skills. Intelligence, (34), 321-350

Şimşek, Ö.F. (2007). Yapısal eşitlik modellemesine giriş. Ankara: Ekinoks Yayıncılık.

Tabachnick, B. G., ve Fidell, L. S. (2001). Principal components and factor analysis. Using Multivariate Statistics, (4), 582-633.

Tavşancıl, E. (2005). Tutumların ölçülmesi ve SPSS ile veri analizi. Ankara: Nobel Yayın Dağıtım.

Tavşancıl, E. ve Aslan, A. E. (2001). Sözel, yazılı ve diğer materyaller için içerik analizi ve uygulama örnekleri. İstanbul: Epsilon Yayınları.

Ulrich, H. F. ve Lehrmann, E. P. (2008). Telecommunications Research Trends. New York, NY, USA: Nova Science Publishers Inc.

Umay, A. ve Arıol, Ş. (2011). Baskın olarak bütüncül şekilde düşünenler ile baskın olarak analitik stilde düşünenlerin problem çözme davranışlarının karşılaştırılması. Pamukkale Üniversitesi Ë̆itim Fakültesi Dergisi, 30(11), 27-37.

\section{ETIK ve BİLIMSEL İLKELER SORUMLULUK BEYANI}

$\mathrm{Bu}$ çalışmanın tüm hazırlanma süreçlerinde etik kurallara ve bilimsel atıf gösterme ilkelerine riayet edildiğini yazar(lar) beyan eder. Aksi bir durumun tespiti halinde Afyon Kocatepe Üniversitesi Sosyal Bilimler Dergisi'nin hiçbir sorumluluğu olmayıp, tüm sorumluluk makale yazarlarına aittir. 


\section{Ek: Lise Öğrencilerinin Analitik Düşünme Ölçeği}

\begin{tabular}{|c|c|c|c|c|c|c|}
\hline & Lise Öğrencilerinin Analitik Düşünme Ölçeği & 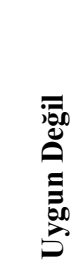 & 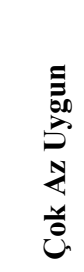 & 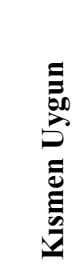 & 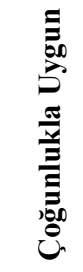 & 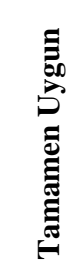 \\
\hline 1. & Bir problemin çözümü için gerekli olan bilgileri belirlerim & (1) & (2) & (3) & (4) & (5) \\
\hline 2. & Karşıma çıkan problem veya konularla ilgili bilgileri irdelerim & (1) & (2) & (3) & (4) & (5) \\
\hline 3. & $\begin{array}{l}\text { Ulaştığım sonuçların birbiriyle karşılaştırarak tutarlılıklarını } \\
\text { kontrol ederim }\end{array}$ & (1) & (2) & (3) & (4) & (5) \\
\hline 4. & $\begin{array}{l}\text { Bir proje üzerinde çalışırken önce genel amacını anlamaya } \\
\text { çalışırım }\end{array}$ & (1) & (2) & (3) & (4) & (5) \\
\hline 5. & $\begin{array}{l}\text { Bir işe veya çalışmaya başlamadan önce, onu nasıl yapacağımı } \\
\text { anlamaya çalışırım. }\end{array}$ & (1) & (2) & (3) & (4) & (5) \\
\hline 6. & Araştırma yaparken yeterince bilgi topladığımdan emin olurum & (1) & (2) & (3) & (4) & (5) \\
\hline 7. & $\begin{array}{l}\text { Problem çözerken kullandığım bilgilerin doğruluğunu } \\
\text { araştırırım. }\end{array}$ & (1) & (2) & (3) & (4) & (5) \\
\hline 8. & Günlük hayatımda karşıma çıkan problemlerin farkına varırım. & (1) & (2) & (3) & (4) & (5) \\
\hline 9. & Kavramlar ve konular arasında neden-sonuç ilişkisi kurarım & (1) & (2) & (3) & (4) & (5) \\
\hline 10. & $\begin{array}{l}\text { Problem hakkındaki bilgi eksikliğimi araştırarak ortadan } \\
\text { kaldırırım }\end{array}$ & (1) & (2) & (3) & (4) & (5) \\
\hline 11. & Konuların genel yönlerinden ziyade detaylarıyla ilgilenirim & (1) & (2) & (3) & (4) & (5) \\
\hline 12. & Ayrıntılara dikkat etmeyi gerektiren konular üzerinde çalışırım & (1) & (2) & (3) & (4) & (5) \\
\hline 13. & $\begin{array}{l}\text { Çalışmaların genel etkileri yerine basamaklarına ve detaylarına } \\
\text { daha fazla dikkat ederim. }\end{array}$ & (1) & (2) & (3) & (4) & (5) \\
\hline 14. & $\begin{array}{l}\text { Problem veya konuların sadece genel sonucunu değil alt } \\
\text { boyutlarını da araştırırım }\end{array}$ & (1) & (2) & (3) & (4) & (5) \\
\hline 15. & Daha çok görevleri dikkat gerektiren işlerde çalışırım & (1) & (2) & (3) & (4) & (5) \\
\hline 16. & $\begin{array}{l}\text { Çözümünde, işlem basamaklarını kendim oluşturacağım } \\
\text { problemler üzerinde daha çok çalışırım }\end{array}$ & (1) & (2) & (3) & (4) & (5) \\
\hline 17. & $\begin{array}{l}\text { Farklı fikirleri kontrol eder ve farklılıkları birbirleri ile } \\
\text { karşılaştırırım }\end{array}$ & (1) & (2) & (3) & (4) & (5) \\
\hline 18. & Çözümlerimde birden fazla ispat kullanırım & (1) & (2) & (3) & (4) & (5) \\
\hline 19. & Soruna ilişkin olası sonuçları göz önünde bulundururum & (1) & (2) & (3) & (4) & (5) \\
\hline 20. & Bir problem durumunu açık ve net bir şekilde ifade ederim & (1) & (2) & (3) & (4) & (5) \\
\hline
\end{tabular}


21. Problemi çözmeden önce kendime çalışma planı yaparım

22. Ders çalışırken, anlayamadı̆̆ım problemlerde tablolar oluşturarak çözümlerim

23. Çalışmaya başlamadan önce konuları kategorilere ayırırım

24. Problemi çözmeden önce hangi adımları izlemem gerektiğini belirlerim
(1)

(1)

(1)

(1)

(2)

(2)

(3)

(4)

(5)

(n) 